\title{
WHAT EVERY PSYCHOLOGIST AND PSYCHOTHERAPIST SHOULD KNOW ABOUT THE PLACEBO AND NOCEBO EFFECT
}

\section{Giacomuzzi Salvatore ${ }^{1}$}

Medical University of Innsbruck, Innsbruck, Austria

salvatore.giacomuzzi@ sfu.ac.at

https://orcid.org/0000-0001-8059-0474

\section{Markus Ertl}

Bureau for statistical studies, Innsbruck, Austria, https://orcid.org/0000-0002-6408-5045

\section{Barinova Natalia}

V. N. Karazin Kharkiv National University, Kharkiv, Ukraine barinova.n2310@gmail.com https://orcid.org/0000-0001-5103-0611

\section{Garber Klaus}

Sigmund Freud University,

Vienna, Austria

klaus.garber@sfu.ac.at

https://orcid.org/0000-0002-0958-0641

\section{Kocharian Alexander}
V. N. Karazin Kharkiv National University, Kharkiv, Ukraine kocharian55@jmail.com https://orcid.org/0000-0001-8998-3370

Purpose. Only a few medical terms are used as often, even in a metaphorically way, as the words placebo and nocebo. Almost any psychologist and psychotherapist think he/she knows well what by a placebo or nocebo is understood, but usually

ISSN 2308-3743 (Online), ISSN 2227-1376 (Print)

(C) Giacomuzzi S., Ertl M., Barinova N., Garber K., Kocharian O., 2021. Ця стаття відкритого доступу на умовах CC BY-NC 4.0 
without really being able to explain it exactly and how it works. In addition, most psychologists and psychotherapists immediately think of clinical trials. However, many things are attributed to the placebo or nocebo effect that does not really fall under this concept in terms of a strict scientific terminology. Therefore, the following article summarizes the ongoing debate on placebo/nocebo effects by citing the current scientific literature.

Methods. To realize the purpose of the study, we used the methods of theoretical scientific research.

Results. In summary patients are more prone to develop nocebo effects are those with alternative or negative healthcare beliefs or experiences or unrealistic perceptions about treatment; managing these factors is a core strategy to counteract the nocebo effect.

Conclusions. Healthcare professionals can help to minimise the influence of the nocebo effect by considering how information about treatments, including benefits and adverse effects, is framed and communicated. Establishing a positive interaction from the start and involving patients in decisions about their treatment and ensuring they understand the cause of their illness and what they can do to manage their symptoms is likely to lead to better treatment outcomes.

Keywords: placebo, nocebo, healthcare, patients, psychotherapist.

Джакомуцці С., Ертл М., Барінова Н., Гарбер К., Кочарян О. Що кожен психолог і психотерапевт повинен знати про ефект placebo i nocebo.

Мета. Лише декілька медичних термінів використовуються так часто, навіть у метафоричному плані, як слова плацебо та ноцебо. Майже будь-який психолог і психотерапевт вважає, що він / вона добре знає, що розуміють під поняттями плацебо або ноцебо, але, зазвичай, не можуть пояснити, як саме це працює. Крім того, більшість психологів та психотерапевтів одразу замислюються про клінічні випробування. Однак багато речей приписують ефекту плацебо або ноцебо, який насправді не підпадає під цю концепцію 3 точки зору суворої наукової термінології. Тому наступна стаття підсумовує поточні дискусії щодо ефектів плацебо / ноцебо, посилаючись на сучасну наукову літературу.

Методи. Для реалізації мети дослідження ми використовували методи теоретичного наукового дослідження.

Результати. Таким чином, пацієнти більш схильні до розвитку ефектів ноцебо - це ті, хто має альтернативні або негативні переконання в галузі охорони здоров'я або досвід або нереальне сприйняття лікування; управління цими факторами є основною стратегією протидії ефекту ноцебо.

Висновки. Медичні працівники можуть допомогти мінімізувати вплив ефекту ноцебо, використовуючи спосіб формування та передачі інформації про лікування, включаючи переваги та несприятливі ефекти. Встановлення позитивної взаємодії з самого початку та залучення пацієнтів до рішень щодо їх лікування та забезпечення розуміння ними причини їхньої хвороби та того, що вони можуть зробити для лікування своїх симптомів, швидше за все, призведе 
до кращих результатів лікування.

Ключові слова: плацебо, ноцебо, охорона здоров’я, пацієнт, психотерапевт.

Джакомуцци С., Эртл М., Баринова Н., Гарбер Клаус, Кочарян А. Что каждый психолог и психотерапевт должен знать об эффекте placebo и nocebo.

Цель. Лишь несколько медицинских терминов используются так часто, даже в метафорическом плане, как слова плацебо и ноцебо. Почти любой психолог и психотерапевт считает, что он / она хорошо знает, что понимают под понятиями плацебо или ноцебо, но, как правило, не могут объяснить, как это работает. Кроме того, большинство психологов и психотерапевтов сразу задумываются о клинических испытаниях. Однако многое приписывают эффекту плацебо или ноцебо, который на самом деле не подпадает под эту концепцию с точки зрения строгой научной терминологии. Поэтому следующая статья подытоживает текущие дискуссии о эффектах плацебо / ноцебо, ссылаясь на современную научную литературу.

Методы. Для реализации цели исследования мы использовали методы теоретического научного анализа.

Результаты. Таким образом, пациенты более склонны к развитию эффектов ноцебо - это те, кто имеет альтернативные или негативные убеждения в области здравоохранения или опыт или нереально восприятие лечения; управления этими факторами является основной стратегией противодействия эффекта ноцебо.

Выводы. Медицинские работники могут помочь минимизировать влияние эффекта ноцебо, используя способ формирования и передачи информации о лечении, включая преимущества и неблагоприятные эффекты. Установление позитивного взаимодействия с самого начала и привлечения пациентов с решениями по их лечению и обеспечения понимания ими причины их болезни и того, что они могут сделать для лечения своих симптомов, скорее всего, приведет к лучшим результатам лечения.

Ключевые слова: плацебо, ноцебо, здравоохранение, пациент, психотерапевт.

\section{Introduction}

As long ago in the ancient near east, the sick were cured by talking to them. The first historical tradition of the „Placebo“ effect comes from Plato. Plato was convinced that words could have the power to heal the sick. Placebo is Latin for I shall be pleasing. It was originally used as a name for the Vespers in the Office of the Dead, taken from a phrase used in it, a quote from the Vulgate's Psalm 116:9.

In the Cambridge dictionary we find e.g. that placebo is a substance 
given to someone who is told that it is a particular medicine, either to make that person feel as if they are getting better or to compare the effect of the particular medicine when given to others. The opposite term "Nocebo" was originally coined to give a name to the negative equivalent of placebo phenomena and distinguish between desirable and undesirable effects of placebos. Therefore, nocebo was used to describe an inactive substance or ineffective procedure that was designed to arouse negative expectations (Häuser, Hansen, Enck, 2021).

Jütte (2011) underlines that the term placebo is known nowadays in the medical terminology for not more than nearly 200 years. It was not until the second third of the 18th century that this phenomenon, or at least one aspect of it, was described with the word "placebo" (Jütte, 2011). However, what is understand today as the placebo effect was not only known to doctors but also to non-physicians but rather as a phenomenon. The first controlled clinical trials were designed in the early 19th century by physicians who either wanted to proof that homeopathy was effective or that this new healing method was rather only nonsense. It was not until the discovery of the Paul Martini (1932), professor of medicine at the University of Bonn, that medical methodology discovered the placebo as a control in drug trials.

In 1955, Henry K. Beecher published the classic work entitled "The Powerful Placebo." Since that time the placebo effect has been considered a scientific fact. Beecher was the first scientist to quantify the placebo effect. He claimed that in 15 trials with different diseases, a placebo alone satisfactorily relieved $35 \%$ of 1082 patients. This publication is still the most frequently cited placebo reference (Kienle, 1997).

By the late 1950s, Beecher had completely reshaped his views on experimental research. He published his first article on research ethics in 1959, continued expressing dismay at the weak safeguards for experimental subjects, and established himself as an authority with his 1966 New England Journal article. When he died, that journal eulogized him as "one of the pioneers in the development of programs designed to protect the rights of patients and of volunteers engaged in various human studies."

Only in a 1965 lecture had Beecher ever hinted publicly that he felt "obliged to say that, in years gone by, work in my laboratory could have been criticized" for its ethical flaws (El-hai, 2017).

Methods. The following article summarizes the ongoing debate on 
placebo/nocebo effects by citing the current scientific literature.

\section{Results and discussion.}

\section{General description regarding the Placebo and Nocebo effect}

In modern scientific literature, a broader concept of placebo is used today. Placebo is understood as the administration of a placebo pharmacognosy or the use of a placebo procedure, as well as the influence of the treatment environment, the expectations of the client and the doctor, and the associated successful therapist-client interaction (Jütte 2011).

Real or pure placebos are „medicines" that only contain a pharmacologically ineffective substance or colorants according to Jütte (2011). An active placebo is a pharmacologically active substance, which, however, does not contain any specific effects for the specific case. Only typical side effects are induced. It is only used in clinical trials.

Pseudo-placebos, also called "unclean placebos" or "impure placebos", are pharmacodynamically active substances which, however, do not have any specific effect on the disease, either because the dosage is too low or because the disease being treated does not respond to them according to the prevailing medical theory underlines Jütte (2011). This placebo variant rarely plays a part in research, while it is of great relevance in daily practice, since pure placebos can only be used in exceptional cases. In contrast to pure placebos, pseudo-placebos can cause specific adverse therapeutic effects due to the pharmacodynamics of the substance used.

In daily routine the balancing between pure placebo and pseudoplacebo regarding the side effect profile of the pseudo-placebo, as well as ethical and legal aspects, should be taken into account.

Let us say now some more words about the nocebo effect and it's implications. A range of studies have identified that a patient's expectations about a treatment is a key factor in influencing rates of adverse effects and medicine adherence.

The nocebo effect, in contrast, is less well known, and derives from Latin for "I will harm". It describes a reduction in treatment efficacy, a worsening of symptoms or new onset adverse effects experienced independently from the action of an active treatment component. This is due to the expectation or perception that the treatment will cause harm. For example, in the study above, when patients were given negative expectations about treatment (i.e., told the opioid would make them more sensitive to pain after the initial effect wore off), the analgesic effect of the 
opioid was completely eliminated (Bingel, Wanigasekera, Wiech, et al., 2011).

It has been suggested that a significant proportion of adverse effects of medicines are attributable to the nocebo effect (The nocebo effect:..., 2019). One explanation of how nocebo-induced symptoms can occur is that because the patient is anticipating that their treatment will result in negative effects, they are likely to have a heightened awareness or sensitivity towards normal day-to-day symptoms, e.g. aches, pains, fatigue, mood changes, and sensory changes (Kaptchuk, Miller, 2015). These symptoms are then attributed to the treatment and considered as an adverse effect. Natural fluctuations in a disease process or symptoms can also be attributed as adverse effects of a treatment if they coincide with the initiation of a different medicine (or brand) or a change in treatment approach.

Häuser et al (2021) state that physicians face an ethical dilemma, as they are required not just to inform patients of the potential complications of treatment, but also to minimize the likelihood of these complications, i.e., to avoid inducing them through the potential nocebo effect of thorough patient information. Possible ways out of the dilemma include emphasizing the fact that the proposed treatment is usually well tolerated, or else getting the patient's permission to inform less than fully about its possible side effects. Communication training in medical school, residency training, and continuing medical education would be desirable so that physicians can better exploit the power of words to patients' benefit, rather than their detriment (Häuser, Hansen, Enck, 2021).

Colloca (2018) underlines that the phenomenon known as the nocebo effect describes the effects of negative expectancies. This is according to Colloca in contrast to positive expectations that trigger placebo effects. In evolutionary terms, nocebo and placebo effects coexist to favour perceptual mechanisms that anticipate threat and dangerous events (nocebo effects) and promote appetitive and safety behaviours (placebo effects) (Colloca, 2018).

The efficacy of placebo has been demonstrated for subjective symptoms such as pain and nausea. Nocebo (and placebo) effects engage a complex set of neural circuits in the central nervous system that modulate the perception of touch, pressure, pain and temperature. Colloca states that nocebo effects contribute to perceived side effects and may influence clinical outcomes and patients' adherence to medication. Therefore, 
according to Colloca we should consider how to avoid them in clinical trials and practices. For example, nocebo effects might be reduced by tailoring patient-clinician communication to balance truthful information about adverse events with expectations of outcome improvement, exploring patients' treatment beliefs and prior negative therapeutic history, and paying attention to framing (ie, treatment description) and contextual effects (ie, price). Through an understanding of the physiological mechanisms, strategies could be developed to reduce nocebo effects (Colloca, Miller, 2011).

Nocebo effects can also arise from a variety of circumstances. There are various factors that influence a patient's attitude towards their treatment, including:

- Healthcare beliefs, such as views on whether medicines are harmful, preferences for complementary or alternative medicines;

- Perceived personal sensitivity to the effects of medicines;

- Perceived severity of their condition, baseline symptoms and comorbidities;

- Previous healthcare experiences, including adverse treatment reactions;

- Level of anxiety;

- Interactions with HealthCare professionales;

- Medicines information, e.g. consumer medicine sheets, package inserts, patient websites;

- Health literacy, e.g. interpretation of written or verbal adverse effect information;

- Mainstream and social media;

- Views and experiences of family, friends and others (Arnold, Finniss, Kerridge, 2014).

\section{Psychological mechanisms}

Placebo and nocebo are meanwhile being used in another sense: The effects of every medical treatment, for example administration of drugs or psychotherapy, are divided into specific and non-specific as we stated above. Specific effects are caused by the characteristic elements of the intervention. The non-specific effects of a treatment are called placebo effects when they are beneficial and nocebo effects when they are harmful (Häuser, Hansen, Enck, 2021).

Placebo and nocebo effects are also seen as psychobiological phenomena that arise from the therapeutic context in its entirety, including 
sham treatments, the patients' treatment expectations and previous experience, verbal and non-verbal communications by the person administering the treatment, and the interaction between that person and the patient. The term "nocebo effect" covers new or worsening symptoms that occur during sham treatment e.g., in the placebo arm of a clinical trial or as a result of deliberate or unintended suggestion and/or negative expectations. "Nocebo response" is used to mean new and worsening symptoms that are caused only by negative expectations on the part of the patient and/or negative verbal and non-verbal communications on the part of the treating person, without any (sham) treatment.

The proven mechanisms of the placebo response include learning by Pavlovian conditioning and reaction to expectations aroused by verbal information or suggestion. Learning experiments with healthy probands have shown that worsening of symptoms of nausea (caused by spinning on a swivel chair) can be conditioned. Expectation-induced cutaneous hyperalgesia could be produced experimentally through verbal suggestion alone. Social learning by observation led to placebo analgesia on the same order as direct experience by conditioning. Nocebo responses can also be demonstrated in patients. In an experimental study, 50 patients with chronic back pain were randomly divided into two groups before a leg flexion test: One group was informed that the test could lead to a slight increase in pain, while the other group was told that the test had no effect on pain level. The group with negative information reported stronger pain and performed fewer leg flexions than the group with neutral instruction (Häuser, Hansen, Enck, 2021).

It can be concluded from these studies that both placebo and nocebo responses can be acquired via all kinds of learning. If such reactions occur in everyday clinical practice, one must assume that they arise from the patient's expectations or previous learning experiences.

Sex or gender is a proven predictor of the placebo response and also exerts some influence on the nocebo response. In the above-mentioned study on the aggravation of symptoms of nausea, women were more susceptible to conditioning and men to generated expectations. Identification of predictors of nocebo responses is a central goal of ongoing investigations. The aim is to pinpoint groups at risk of nocebo responses, for example patients with high levels of anxiety, and optimize the therapeutic context accordingly (Häuser, Hansen, Enck, 2021).

The nocebo effect is a decrease in subjective benefit, a worsening of 
symptoms or onset of adverse effects due to an expectation or perception of harm associated with a medicine or other treatment. The nocebo effect is influenced by factors such as healthcare beliefs, previous experiences, health professional interactions, written and verbal information about medicines, mainstream and social media and social modelling (modified behaviour due to observation of others response to treatment). Medicine adherence, treatment outcomes and future health decisions are affected by the perception of adverse effects. Nocebo effects are more common in patients with increased levels of anxiety who report high levels of baseline symptoms. The nocebo effect can be minimised by reducing negative expectations and anxiety about treatment, and placing discussion about the likelihood of adverse effects into the context of treatment benefit (Olesen, 2015).

The verbal and non-verbal communications contain numerous unintentional negative suggestions that may trigger a nocebo response. Patients are highly receptive to negative suggestion, particularly in situations perceived as existentially threatening, such as impending surgery, acute severe illness, or an accident. Persons in extreme situations are often in a natural trance state and thus highly suggestible. This state of consciousness leaves those affected vulnerable to misunderstandings arising from literal interpretations, ambiguities, and negative suggestion (Petrie, Rief, 2019).

\section{Strategies to reduce the nocebo effect}

Depending on the individual situation, it may be appropriate to directly discuss the nocebo effect with patients and how this might affect their treatment experience. Avoid unintended negative suggestion in everyday clinical practice (according to Häuser et al (2021))

\section{- Causing uncertainty}

"This treatment/medication may help."

"Let's try this treatment/drug."

"Try to take your meds regularly."

\section{- Jargon}

"We're wiring you up now." (Connection to the monitoring device)

"Then we'll cut you into lots of thin slices." (Computed tomography)

"Now we're hooking you up to the artificial nose." (Attaching an oxygen mask)

"We looked for metastases - the result was negative."

\section{- Ambiguity}


"We'll just finish you off." (Preparation for surgery)

"We're putting you to sleep now, it'll soon be all over." (Induction of anesthesia)

'I'll just fetch something from the 'poison cabinet' (secure storage for anaesthetics), then we can start."

\section{- Emphasizing the negative}

"You are a high-risk patient."

"That always hurts a lot."

"You must strictly avoid lifting heavy objects-you don't want to end up paralyzed."

"Your spinal canal is very narrow-the spinal cord is being compressed."

\section{- Focusing attention}

"Are you feeling nauseous?" (Recovery room)

"Signal if you feel pain." (Recovery room)

\section{- Ineffective negation and trivialization}

"You don't need to worry."

"It's just going to bleed a bit."

Further strategies to reduce the incidence or impact of nocebo and adverse effects are (Bingel, 2014; Chavarria, Vian, Pereira, et al., 2017; Howick, 2012):

- Consider how patients perceive their condition, their understanding of what causes it, why they think it happened when it did

- Ask the patient about how severe they think their condition is, how long they think it will persist, what symptoms they are most affected by and what makes it worse or better.

- Establish what outcome the patient wants; what are the main symptoms/problems they want help with? What do they expect from treatment?

- From the healthcare professional's perspective: empathise, ensure you have understood their beliefs or opinions, explain back your perceptions of the problem

- Discuss treatment options, including non-pharmacological or no treatment approaches if appropriate. Establish the patient's preference for treatment. This provides patients with a sense of control and ownership over their management plan. 
- Ask patients what they understand about the effects and benefits of their treatment; this establishes the patient's attitude and perceptions towards the treatment.

- Consider the patient's previous experiences, e.g. using the same medicine or another medicine for the same condition, have they experienced adverse medicine effects or had other negative healthcare experiences

- Consider how adverse effects are communicated (see: "Phrasing and framing the risks of adverse effects"). Balance the risk of adverse effects with the treatment benefit and use positive framing when discussing risk, e.g. the percentage of patients who improve with treatment and remain free of adverse effects

- Discuss adverse effects that settle over time and strategies for managing minor adverse effects; this can help to encourage perseverance with treatment

- Provide reassurance that any problems that arise will be addressed and ensure patients know when to seek medical treatment for serious adverse effects

- Ask patients to "teach-back" what has been discussed, i.e. explain or demonstrate in their own words. Any negative biases or misunderstandings can be discussed again.

- Focus on benefits of the treatment

- Alleviate anxiety about treatment and medicine

In recent years, the impact of media presentations of health on individual patient's treatment expectations gained increasing relevance. Therefore, discussing and possibly correcting negative expectations, which patients gained by media consumption, in relation to the occurrence of nocebo effects, need to be considered during treatment as well. To conclude, the issue of nocebo effects, which occur as a consequence of informing patients about the prognosis of their symptoms, including the disclosure of possibly occurring adverse reactions after treatment, is subject of an ongoing debate.

\section{Nocebo Effects in Psychotherapy}

The question arises now which role nocebo effects may play in the context of psychotherapy. There is as little doubt as much as there is empirical proof that psychotherapy is an effective intervention for psychological problems and disorders. However, there is ongoing controversy about the mechanisms underlying these often impressive, but 
also often overestimated effects, reaching back to the very origins of psychotherapy research. While this "great psychotherapy debate" vivifies both psychotherapy research and practice, it finally poses an ethical challenge for both psychotherapists and psychotherapy scholars. Basically, the lack of agreed and validated mechanisms impedes the attempt to inform patients about how changes of psychotherapy are brought about. Thus, even though patients can readily be furnished with possible and expectable benefits, costs and strains, the situation becomes more complex and less certain with regard to the specific mechanisms and determinants of change (Gaab, Locher, Trachsel, 2021).

Interestingly and relevant the possible negative effects of psychotherapy were common lore in the 1960s as Barlow points out, "Being awakened to the possibility that one could inflict dire harm on patients during each visit to the consulting room (or even on the way to it) was an ever-present source of anxiety during those early years for many of us" . This "dire harm" could consist of the "Pavlovian construct of transmarginal inhibition or a state of complete shutdown of the organism," being inflicted through "intense experiences". Accordingly, although psychotherapy of course can have negative consequences, such as negative side effects but also no improvement of symptoms or even symptom worsening, these are regrettably underreported and underinvestigated in psychotherapy research. Recently, however, symptom deterioration in waiting-list control groups has been described as possibly being caused by the same mechanisms that cause nocebo effects (36): The authors argue that negative expectations regarding the hypothesized inactive control treatment and the assumption that patients give up their coping strategies while waiting for a promised effective treatment have been described to explain the observed symptom deterioration. Following a similar line of argumentation, we discuss two examples to illustrate two possible associations between psychotherapy and nocebo effects, and we analyse whether symptom deterioration or no improvement observed in psychotherapy may be related to nocebo mechanisms.

In the context of chronic primary pain, we identified relevant nocebo mechanisms that may occur during treatment of chronic pain, including mainly the creation of negative expectations. Thus, patients with chronic pain may reflect a population with a particularly high risk for the occurrence of nocebo effects. However, this is also valid for other patient populations with symptoms e.g., medically unexplained symptoms or 
mental disorders, such as depression. This highlights the need for a flexible treatment approach, to address patients with pre-existing treatment experiences, their negative expectations and motivations, and their subjective illness and healing narratives. Negative treatment expectations have been demonstrated to be related to negative treatment effects in other domains of health care. The highly individualized approaches of most psychotherapeutic treatments offer the possibility to address these issues. Thus, psychotherapy may be seen as a means to reduce nocebo effects in the treatment of chronic pain.

At least some of the mechanisms that are assumed to be the cause of no improvement or even deterioration of symptoms after debriefing of trauma survivors are the same that underlie nocebo effects-most importantly, the creation of expectations regarding the occurrence of PTSD symptoms. Accordingly, just as it has been discussed in the context of other health care settings, debriefing of patients regarding possibly occurring symptoms may contribute to nocebo effects in the context of psychotherapy as well (Locher, Koechlin, Gaab, Gerger, 2019).

In terms of recommendations for clinical practice, for Locher et al (2019) the most relevant question is, "How can the occurrence of nocebo effects best be avoided within an ethical framework?" In the context of psychotherapeutic treatments, this essentially involves:

- $\quad$ first, to speak openly and honestly about the possible occurrence of nocebo effects in the course of psychotherapy;

- second, to address possible adverse responses to psychotherapeutic treatment;

- third, with respect to the importance of the narrative, the choice of words should be carefully considered in treatment settings, taking into account the patient's own background and understanding (i.e., the patient's subjective illness narrative).

\section{Conclusions.}

In summary patients are more prone to develop nocebo effects are those with alternative or negative healthcare beliefs or experiences or unrealistic perceptions about treatment; managing these factors is a core strategy to counteract the nocebo effect. Healthcare professionals can help to minimise the influence of the nocebo effect by considering how information about treatments, including benefits and adverse effects, is framed and communicated. Establishing a positive interaction from the start and involving patients in decisions about their treatment and ensuring 
they understand the cause of their illness and what they can do to manage their symptoms is likely to lead to better treatment outcomes.

Particularly psychiatric patients are not only treated with pharmacotherapy but often with different forms of psychotherapy. The role and mechanisms of the placebo effect in psychotherapy has been repeatedly discussed, and Enck and Zipfel (2019) point to the challenges of disentangling specific effects of the different psychotherapeutic approaches including unspecific and the placebo effect. This is even more challenging when considering that many psychotherapeutic approaches are equally effective and there is still a debate within psychotherapy research about the specific, common and unspecific factors. Enck and Zipfel encourage psychotherapy researchers as well as therapists to understand that the placebo effect exists and provide a framework that acknowledges context, common, and specific factors for further research (Weimer et al., 2020).

We conclude in accordance with Weimer et al (2020) that placebo and nocebo effects are a complex phenomenon. There is still a debate about the role of placebo and nocebo effects in psychotherapy and their relation to common and context factors. In contrast, context factors such as the patient-provider interaction have already been acknowledged as part of the placebo effect in other treatments. Research about the placebo effect on depression, anxiety, and pain reveals a high placebo effect showing symptom improvement and neurophysiological changes in the brain. Recent studies aim to harness the placebo effect to improve functions that are related to mental disorders, such as cognitive functioning or appetite regulation, and may be an interesting research area for further studies.

\section{Referances}

1. Jütte, R. (2011). Placebo: Mehr als nur Einbildung. Ärzteblatt Sachsen, 5, 215-219.

2. Martini, P. (1932). Methodenlehre der Therapeutischen Untersuchung. Berlin: Springer.

3. Kienle, G.S. (1997). The powerful placebo effect: fact or fiction? J Clin Epidemiol, 50(12),1311-8. doi: 10.1016/s0895-4356(97)00203-5.

4. El-hai, J. (2017). Henry Knowles Beecher: Brief life of a late-blooming ethicist: 1904-1976. Harvard Magazine. https://harvardmagazine.com/2017/03/henry-knowles-beecher

5. Bingel U., Wanigasekera V., Wiech K., et al. (2011). The effect of treatment expectation on drug efficacy: imaging the analgesic benefit of the opioid 
remifentanil. Sci Transl $\quad$ Med, 3 :70ra14. http://dx.doi.org/10.1126/scitranslmed.3001244

6. The nocebo effect: what is it, why is it important and how can it be reduced? (2019). https://bpac.org.nz/2019/nocebo.aspx\#3

7. Kaptchuk T.J., Miller F.G. (2015). Placebo effects in medicine. $N$ Engl J Med, 373, 8-9. http://dx.doi.org/10.1056/NEJMp1504023

8. Häuser, W., Hansen, E., Enck P. (2021). Nocebo Phenomena in Medicine: Their Relevance in Everyday Clinical Practice. Dtsch Arztebl Int. 109(26), 459-465.

9. Colloca L. (2018). Nocebo effects can make you feel pain. Negative expectancies derived from features of commercial drugs elicit nocebo effects. Science. 358(6359): 44. doi: 10.1126/science.aap8488

10. Colloca, L., Miller F.G. (2011). The nocebo effect and its relevance for clinical practice. Psychosom Med. 73; 598.

11. Arnold M.H,, Finniss D.G., Kerridge I. (2014). Medicine's inconvenient truth: the placebo and nocebo effect. Intern Med J, 44, 398-405. http://dx.doi.org/10.1111/imj.12380

12. Olesen F. (2015). Beyond the placebo: understanding the therapeutic context. Br J Gen Pract, 65, 6-7. http://dx.doi.org/10.3399/bjgp15X683017

13. Petrie K.J., Rief W. (2019). Psychobiological Mechanisms of Placebo and Nocebo Effects: Pathways to Improve Treatments and Reduce Side Effects. Annu Rev Psychol, 70, 599-625. http://dx.doi.org/10.1146/annurev-psych-010418-102907

14. Bingel U, (2014). Placebo Competence Team. Avoiding nocebo effects to optimize treatment outcome. JAMA, 312, 693-4. http://dx.doi.org/10.1001/jama.2014.8342

15. Chavarria V, Vian J, Pereira C, et al. (2017). The placebo and nocebo phenomena: their clinical management and impact on treatment outcomes. Clin Ther, 39, 477-86. http://dx.doi.org/10.1016/j.clinthera.2017.01.031

16. Howick J. (2012). Saying things the 'right' way: avoiding 'nocebo' effects and providing full informed consent. Am $J$ Bioeth, 12, 33-4. http://dx.doi.org/10.1080/15265161.2012.656799

17. Gaab J., Locher C., Trachsel M. (2021). The Ethics of Placebo and Nocebo in Psychotherapy. The Oxford Handbook of Psychotherapy Ethics. DOI: 10.1093/oxfordhb/9780198817338.013.32

18. Locher C., Koechlin H., Gaab J.Gerger H. (2019). The Other Side of the Coin: Nocebo Effects and Psychotherapy. Front Psychiatry, 10, 555.

19. Enck P., Zipfel St. (2019). Placebo Effects in Psychotherapy: A Framework. Front. Psychiatry, 26. https://doi.org/10.3389/fpsyt.2019.00456

20. Weimer K, Enck P., Dodd S., Colloca L. (2020). Editorial: Placebo and Nocebo Effects in Psychiatry and Beyond. Front Psychiatry, 11, 801.

Received: 03.05.2021

Accepted: 26.05.2021 